\title{
EXCERPTS FROM THE 100-DAY FOOD DIARY OF ANGELA MEYER
}

\section{The road to change.}

\section{BY BETH CATO}

Day 1: My therapist asked me to start this 100-day food diary to help me with accountability for my eating disorder. She knows (hi, Tammy!) that my honest, gullible nature means I'll tell the truth about what I eat and why. She also knows that my obsessivecompulsive disorder will compel me to record everything daily. So far, the meds haven't decreased my ritual behaviours much, especially in regards to stress and food. Here's hoping this diary helps.

Day 11: Today, Lindsay gave me a chocolate cake. AN ENTIRE CAKE. She's purposefully sabotaging me, and it makes me angry and sad. (See, Tammy? I'm employing the 'feelings language' you want me to use.) I think she's scared for our friendship now that I have professional help with my diet. After all, me and Lindsay are the 'two fat chicks' in the office. She's used me as a partner to help her sabotage her own diet attempts before.

I ate a small piece of cake at my desk, just to placate her. I've done so well for 11 days, and now this! The cake is sheer heaven, too. Chocolate sponge with buttercream filling and ganache on top. Guilt makes me want to throw up, but I crave more cake.

Day 12: I'm genuinely grateful, Tammy, for how you handled my phone call after I ate another piece. The Garcias in the apartment next door were happy to accept the remaining cake from me.

My anxiety is lower now that I know the cake won't go to waste.

A few weeks ago, I would have eaten that whole thing as fast as possible so that it wouldn't go stale, and then starved myself for the next week to compensate. I stayed on the programme today, Tammy, but I won't lie. The sugar craving is like an itch.

Day 21: Too stressed to eat much today, which I think is a first for me. I can't believe the news is all about talk of possible nuclear war. This feels unreal.

$\begin{array}{ll}\text { DNATURE.COM } & \text { I loaded up on pro- } \\ \text { Follow Futures: } & \text { cessed crackers and } \\ \text { @NatureFutures } & \text { high-sodium canned } \\ \text { f go.nature.com/mtoodm } & \text { soups at the grocery }\end{array}$

store today, but I don't have any interest in eating them. I just feel better with a food stockpile. Besides, I can donate the food to the mission downtown as it nears the holidays.

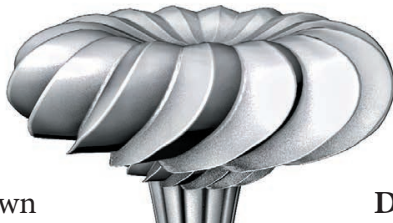

worth a fortune. I suppose I won't need to worry about insurance deductibles when I see you again. I can pay in codeine!

Day 67: Fighter planes overhead throughout the day triggered bad panic attacks for me. I didn't even try to eat. Can't Day 27: I'd kill for a hamburger
and garlic fries. I need to and garlic fries. I need to
switch salad recipes or something, because I'm of legitimate anxiety. Happy getting sick to death of the same lunch every day.

Addendum: I ate a handful of baby carrots and drank two glasses of water. Still craving junk, but I'm satiated enough to make it till bedtime.

Day 40: I can't believe this. I woke up and just thought the power was out, but Paloma from next door told me there'd been attacks, maybe millions dead. Must be gossip and hysteria. My appetite is gone, in any case. Only had two smoothies today.

Day 41: Power still out. It's Monday, but I didn't go to work; doesn't look safe. I pulled out frozen chicken breasts to thaw and cooked them on my gas stove, and I'll do it again tomorrow to clear out my freezer. I teamed up with the Garcias to take food from our fridges down to the basement where it's staying cold.

Day 45: Power still out. Don't hear sirens anymore. The Garcias left for the country. Lots of people are leaving, many on foot. I'm constantly hungry, but I'm only letting myself eat a few times a day, in set quantities.

Day 55: Hey Tammy, the apocalypse diet is working great, ha ha. I think I'm down two sizes.

Day 64: Killed a man. Came in from dumping my toilet bucket, found him raiding my cupboards. I caught him off guard, and it was done in seconds. His backpack was loaded with energy bars (YAY!), couple of guns, lots of prescription drugs. This stuff must be birthday to me.

Day 81: Somewhere south of the interstate now. This area hasn't burned yet. Need to find shelter for the night. I watched the fire drift my way for hours, so I was ready to go. Filled the Garcias' baby stroller with lots of food and water.

Space is tight, but I brought this diary because it's almost full of paper. And I like to pretend I'm talking to you, Tammy. I hope you're alive. I hope I can tell you how much your advice has sustained me over these awful weeks.

Day 90: Suburbs largely abandoned. Traded pills for access to water. Getting low on food.

Day 95: Attacked yesterday. Hurt badly. Head, ribs. Lost a lot of blood. This book is about all they left me. Might need to start eating it. Paper's a low-calorie food, right, Tammy? Don't want to stray from the diet plan and undo my great weight-loss progress.

Day 99: Found a wrecked, loaded bakery truck hidden in an overgrown ditch off the road. Boxes of bread loaves, coffee cakes, wrapped muffins. I had a few bites of stale whole wheat bread softened by rainwater. It tasted wonderful. It satiated me.

I'm surrounded by cakes and not even craving them. Tammy, you'd be so proud. -

Beth Cato resides in Arizona. She is the author of the Clockwork Dagger steampunk fantasy series from Harper Voyager. Her website is BethCato.com. 